\title{
Identification of Fungal Communities Within the Tar Spot Complex of Corn in Michigan via Next-Generation Sequencing
}

\author{
A. G. McCoy, ${ }^{1}$ M. G. Roth, ${ }^{1,2}$ R. Shay, ${ }^{3}$ Z. A. Noel, ${ }^{1,4}$ M. A. Jayawardana, ${ }^{1}$ R. W. Longley, ${ }^{5}$ G. Bonito,,${ }^{1,4,5, \dagger}$ \\ and M. I. Chilvers ${ }^{1,2,4, \dagger}$ \\ ${ }^{1}$ Department of Plant, Soil and Microbial Sciences, Michigan State University, East Lansing, MI 48824 \\ ${ }^{2}$ Genetics Graduate Program, Michigan State University, East Lansing, MI 48824 \\ ${ }^{3}$ Department of Plant Biology, Michigan State University, East Lansing, Ml 48824 \\ ${ }^{4}$ Program in Ecology, Evolutionary Biology, and Behavior, Michigan State University, East Lansing, \\ MI 48824 \\ ${ }^{5}$ Department of Microbiology and Molecular Genetics, Michigan State University, East Lansing, MI 48824 \\ Accepted for publication 6 July 2019.
}

\begin{tabular}{|c|c|}
\hline \multicolumn{2}{|c|}{ ABSTRACT } \\
\hline $\begin{array}{l}\text { Tar spot is a fungal disease complex of corn that has been } \\
\text { destructive and yield limiting in Central and South America for } \\
\text { nearly } 50 \text { years. Phyllachora maydis, the causal agent of tar spot, } \\
\text { is an emerging corn pathogen in the United States, first reported in } \\
2015 \text { from major corn producing regions of the country. The tar } \\
\text { spot disease complex putatively includes Monographella maydis } \\
\text { (syn. Microdochium maydis), which increases disease damage } \\
\text { through the development of necrotic halos surrounding tar spot } \\
\text { lesions. These necrotic halos, termed "fish-eye" symptoms, have } \\
\text { been identified in the United States, though Monographella maydis } \\
\text { has not yet been confirmed. A recent surge in disease severity and } \\
\text { loss of yield attributed to tar spot in the United States has led to } \\
\text { increased attention and expanded efforts to understand the } \\
\text { disease complex and how to manage it. In this study, next- } \\
\text { generation sequencing of the internal transcribed spacer } 1 \text { (ITS1) } \\
\text { ribosomal DNA was used to identify fungal taxa that distinguish tar } \\
\text { spot infections with or without fish-eye symptoms. Fungal } \\
\text { communities within tar spot only lesions were significantly different } \\
\text { from communities having fish-eye symptoms. Two low abundance }\end{array}$ & $\begin{array}{l}\text { operational taxonomic units (OTUs) were identified as } \\
\text { Microdochium sp., however, neither were associated with fish-eye } \\
\text { symptom development. Interestingly, a single OTU was found to } \\
\text { be significantly more abundant in fish-eye lesions compared with } \\
\text { tar spot lesions and had a } 91 \% \text { ITS1 identity to Neottiosporina } \\
\text { paspali. In addition, the occurrence of this OTU was positively } \\
\text { associated with Phyllachora maydis fish-eye symptom networks, } \\
\text { but not in tar spot symptom networks. Neottiosporina paspali has } \\
\text { been reported to cause necrotic lesions on various monocot } \\
\text { grasses. Whether the related fungus we detected is part of the tar- } \\
\text { spot complex of corn and responsible for fish-eye lesions remains } \\
\text { to be tested. Alternatively, many OTUs identified as Phyllachora } \\
\text { maydis, suggesting that different isolate genotypes may be } \\
\text { capable of causing both tar spot and fish-eye symptoms, } \\
\text { independent of other fungi. We conclude that Monographella } \\
\text { maydis is not required for fish-eye symptoms in tar spot of } \\
\text { corn. } \\
\text { Keywords: agriculture, metagenomics, mycology, plant pathology }\end{array}$ \\
\hline
\end{tabular}

${ }^{\dagger}$ Corresponding authors: M. I. Chilvers; chilvers@msu.edu,

and G. Bonito; bonito@msu.edu

First, second, third, and fourth authors contributed equally to this work.

Author contributions: A.G.M., M.G.R., R.S., M.A.J., G.B., and M.I.C. planned experiments. A.G.M., M.G.R., R.S., and M.A.J. collected and processed samples. R.W.L. performed PCR and constructed libraries. A.G.M. submitted raw sequences to

This article is in the public domain and not copyrightable. It may be freely reprinted with customary crediting of the source. The American Phytopathological Society, 2019
Sequence Read Archives. M.G.R. and Z.A.N. analyzed data and generated figures. A.G.M., R.S., M.G.R., Z.A.N., and M.A.J. wrote the manuscript.

Funding: Support was provided by Project GREEEN, the Corn Marketing Program of Michigan, and the Department of Plant, Soil and Microbial Sciences for teaching and research support. R. W. Longley acknowledges the PBHS Biotechnology Training Program Project NIH T32-GM110523 for graduate research fellowship support.

*The $\boldsymbol{e}$-Xtra logo stands for "electronic extra" and indicates that three supplementary figures are published online.

The author(s) declare no conflict of interest. 
Corn (Zea mays) is the most planted feed grain in the United States, with more than 90 million acres in production each year having a net value of approximately 48 billion dollars (U.S. Department of Agriculture-Agriculture Research Service). Each year, diseases of corn cause an estimated $10.8 \%$ reduction in yield (Mueller et al. 2017). Many biotic factors can contribute to yield loss. These include foliar diseases such as northern corn leaf blight (Exserohilum turcicum), gray leaf spot (Cercospora zea-maydis), and southern rust (Puccinia sorghi). Mueller et al. (2017) estimated that corn yield loss due to foliar diseases was 816 million bushels in 2016. Foliar pathogens can individually cause disease or may exist with other pathogens as a disease complex.

One challenging example of a foliar disease complex is tar spot of corn. The tar spot complex of corn is reported to be comprised of two fungal species; Phyllachora maydis and Monographella maydis (syn. Microdochium maydis) (Hock et al. 1989; Müller and Samuels 1984). A third species, Coniothyrium phyllachorae, has also been implicated in this disease complex as a potential hyperparasite of Phyllachora maydis (Hock et al. 1992). Disease symptoms first develop from Phyllachora maydis infections via windblown ascospores, typically at temperatures between 16 to $20^{\circ} \mathrm{C}$, and under high relative humidity over long periods (PereydaHernández et al. 2009). Phyllachora maydis causes small, raised black spots (perithecia) on corn leaves, which are reported to only have a minor impact on the plant (Fig. 1A) (Hock et al. 1995). However, the literature suggests that subsequent infections by Monographella maydis around a Phyllachora maydis lesion creates a necrotic halo surrounding the tar spot lesion, causing the colloquially named "fish-eye" (Fig. 1B) (Chalkley 2010). These fish-eye lesions can quickly coalesce into leaf blight and are reported to cause up to $50 \%$ yield losses (Hock et al. 1989).

Phyllachora maydis was first observed in the United States in 2015 on commercial corn hybrids in Illinois and Indiana (Ruhl et al. 2016). Since then, Phyllachora maydis has been reported and confirmed in Florida, Iowa, Michigan, and Wisconsin (McCoy et al. 2018). In Michigan, there are reports of yield losses of up to 50 bushels per acre (M. Chilvers, unpublished data). Although fish-eye symptoms have been observed in multiple fields and states, researchers and diagnosticians in the United States have been unsuccessful in isolating Monographella maydis from fish-eye lesions. Monographella maydis is commonly isolated from fish-eye symptoms in Mexico, where it is identified based on morphological characters (CIMMYT, personal communication). The inability to culture Monographella maydis from lesions with fish-eye symptoms in the United States has led to subsequent questions regarding the biological components required for fish-eye symptoms to develop in the tar spot complex of corn.

This study utilized a culture-independent approach to investigate fungal species involved in the development of fish-eye symptoms in corn leaves. An understanding of the fungal microbiome associated
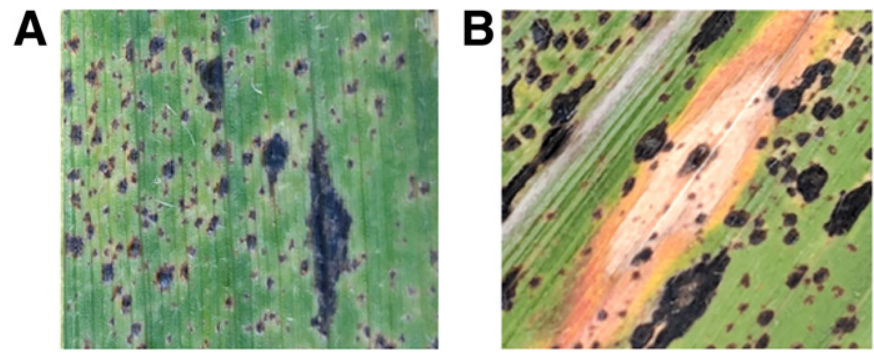

Fig. 1. A, Tar spot lesions and B, a fish-eye necrotic halo surrounding a tar spot lesion on corn leaves found in a Michigan corn field in 2018. with the tar spot disease complex may help reveal the biological complexity involved in symptom development and provide insights to develop better management strategies. Next-generation sequencing of the internal transcribed spacer (ITS) rDNA was used to address the following questions: Is Monographella maydis associated with fish-eye symptomatic plants in Michigan? How do fungal communities within tar spot and fish-eye symptoms differ? What members of the fish-eye symptom community could facilitate symptom development?

\section{MATERIALS AND METHODS}

Sample collection and processing. Corn leaf samples were collected on 17 September 2018 from a symptomatic field at the R5 growth stage in Montcalm County, Michigan, U.S.A. Sampled leaves were sprayed and wiped with $70 \%$ ethanol, and then dried with sterile paper towels. Lesions and surrounding leaf tissue were excised using a flame-sterilized cork borer (18 mm diameter). Excised leaf discs were placed directly into a DNA extraction buffer (Omega Bio-Tek) with flame-sterilized forceps. Tar spot lesions with and without fish-eye symptoms were collected from throughout the field. In total, 48 samples were collected. These consisted of 20 tar spot only lesions, 20 tar spot lesions with fish-eye symptoms, four nonsymptomatic leaf samples (controls), and an additional two samples of each lesion type (tar spot only and fisheye) which were not surface sterilized with $70 \%$ ethanol before sampling (sterilization controls). Sampled tissues were stored in the extraction buffer at $4^{\circ} \mathrm{C}$ until total DNA was extracted using the Omega Mag-Bind Plant DNA DS kit (Omega Bio-Tek). For simplicity, these two lesion types are subsequently referred to as tar spot and fish-eye.

PCR amplification and next-generation sequencing. Illumina MiSeq libraries were generated through PCR ligation consisting of three separate PCR amplifications for target enrichment, adaptor ligation, and barcode tagging. Library preparation and sequencing follows the methods as described by Chen et al. (2018). Briefly, 10 cycles of an enrichment PCR amplification of the ITS region was done in a $12-\mu$ l reaction using $1 \mu \mathrm{l}$ of total DNA, $6.25 \mu \mathrm{l}$ of DreamTaq Green $2 \times$ Master Mix (Thermo Fisher, U.S.A.), $0.375 \mu \mathrm{l}$ of $10 \mu \mathrm{M}$ primers ITS1F (CTT GGT CAT TTA GAG GAA GTA A) (Gardes and Bruns 1993), ITS4 (TCC GCT TAT TGA TAT GC) (White et al. 1990), and $1 \mu \mathrm{l}$ of $3 \%$ bovine serum albumin (BSA). A second 10-cycle PCR ligation of Illumina adaptors was performed using $2 \mu \mathrm{l}$ of the first PCR product, $6.25 \mu$ l of DreamTaq Green $2 \times$ Master Mix, $1 \mu \mathrm{l}$ of $3 \%$ BSA, $2 \mu \mathrm{l}$ of water, and $0.375 \mu \mathrm{l}$ of $10 \mu \mathrm{M}$ ITS1F and ITS4 primers that contained frameshifts (Lundberg et al. 2013). The 15-cycle final amplification and PCR ligation of barcode primes and Illumina adaptors used $4 \mu \mathrm{l}$ of the second PCR product, $8 \mu \mathrm{l}$ of DreamTaq Green $2 \times$ Master Mix, $1 \mu \mathrm{l}$ of 3\% BSA, $0.5 \mu \mathrm{l}$ of water, $1 \mu \mathrm{l}$ of sequencing barcode, and $0.5 \mu \mathrm{l}$ of $10 \mu \mathrm{M}$ PCR $\mathrm{f}$ (New England Biolabs, U.S.A.), a primer which has the Illumina adaptors attached.

PCR amplifications were performed in an Applied Biosystems 2720 Thermal cycler. PCR products were then normalized to $25 \mathrm{ng}$ using a Sequal Prep Normalization Plate Kit (Applied Biosystems). All samples were pooled and concentrated with Amicon Ultra $0.5 \mathrm{ml} 50 \mathrm{~K}$ Centrifugal Filters (EMD Millipore, Germany). Concentrated DNA was purified with AMPure XP magnetic beads (Beckman Coulter, U.S.A.) at a ratio of $0.7 \times$ (magnetic beads: DNA) before being sent to the Research Technology Support Facility at Michigan State University for sequencing on an Illumina MiSeq using V3 reagents (Illumina, U.S.A.).

Bioinformatic data analysis. While both ITS1 and ITS2 sequences were generated in this study, the quality and coverage of 
ITS1 forward reads were superior. Thus, only forward sequence reads were used in the analyses. A sequence quality check was performed to identify high-quality bases using FastQC (http:// www.bioinformatics.babraham.ac.uk/projects/fastqc/) before samples were demultiplexed with custom Python scripts and Quantitative Insights Into Microbial Ecology (QIIME, version 1) (Caporaso et al. 2010). Illumina adaptors and sequencing primers were then removed from samples with Cutadapt (Martin 2011). Quality sequences were trimmed from $300 \mathrm{bp}$ to include $244 \mathrm{bp}$ of ITS-1 rDNA with an expected error per read of 1 (Edgar and Flyvbjerg 2015) This removes the conserved small subunit (SSU) and 5.8S rDNA, so as not to impair clustering and taxonomic assignments. Then the reads were de-replicated, and singleton sequences were removed. Remaining sequences were clustered into operational taxonomic units (OTUs) based on 97\% similarity with custom Python scripts and the UPARSE algorithm (Edgar 2013). Taxonomic assignment of OTUs was performed with CONSTAX at the default assignment threshold of 0.8 (Gdanetz et al. 2017) and the general UNITE ITS database (Release 1-12-17, https://plutof.ut.ee/ \#/datacite/10.15156/BIO/587475) appended with Phyllachora maydis, Microdochium sorghi, and Fusarium acuminatum sequences. Sequences highlighted in subsequent analyses were also identified using a BLAST search to corroborate taxonomic assignment with CONSTAX. A rarefaction curve was generated to confirm sufficient sequence depth across samples (Supplementary Fig. S1).

Statistical analysis. All analyses were performed in $\mathrm{R}$ version 3.3.3 (R Core Team 2017). Data files were imported and converted to 'phyloseq' class, filtered, and pruned with the package 'phyloseq' (McMurdie and Holmes 2013). Reads were transformed into relative abundances based on the total library size before analyses using 'transform_sample_counts' from 'phyloseq'. The number of reads for each OTU was normalized by the sum of reads for each sample, using $\mathrm{X}_{\mathrm{OTU}} /$ sum $\left(\mathrm{X}_{\text {all OтUs }}\right)$, where $\mathrm{X}_{\mathrm{OTU}}$ indicates the total number of reads in a sample for a given OTU and $X_{\text {all OTUs }}$ indicates all OTU reads for a given sample. The relative abundances were plotted using 'plot_bar' from 'phyloseq' to broadly examine the community structure of each sample type before statistical analyses.

Nonsymptomatic control samples were not included in analyses comparing tar spot with fish-eye communities. Alpha diversity (Shannon's index), richness, and evenness were examined using 'estimate_richness' from the 'phyloseq' package on raw, nonnormalized OTU data (McMurdie and Holmes 2014). All 735 identified OTUs were used for within sample ( $\alpha$-diversity) estimation and plotted with the 'plot_richness' function in phyloseq. Fungal communities (735 taxa) were pruned to include only OTUs observed at least five times in at least five percent of samples for between sample ( $\beta$-diversity) estimation. The pruned OTU table included 218 taxa, of which 192 were classified taxonomically to phylum level or beyond. Principal coordinates analysis (PCoA) was conducted with normalized OTU counts using Bray-Curtis (abundance-based) (Michie 1982) and Jaccard (presence/absencebased) (Real and Vargas 1996) distances to visualize relative differences in community composition between tar spot and fisheye lesions. The PCoA was visualized in 'ggplot2' (Wickham 2009). Ellipses were added to the PCoA plot using a $95 \%$ confidence interval for each lesion type. A homogeneity of variance test and a permutational multivariate analysis of variance (PERMANOVA) were performed to test for differences in fungal community centroids and $\beta$-dispersion using the 'betadisper' and 'adonis' functions, respectfully, from the 'vegan' package (Oksanen et al. 2016). Taxa (OTUs) were plotted on the PCoA as black circles, with black triangles representing unique Phyllachora maydis OTUs. Individual OTUs of interest were labeled manually.
Two analyses were used to identify individual OTUs associated with fish-eye or tar spot symptoms to minimize false discovery and to provide statistical significance of individual OTUs manually highlighted in the PCoA; analysis of composition of microbiomes (ANCOM) (Mandal et al. 2015) and indicator species analysis. Indicator species analysis was performed with the 'multipatt' function of the 'indicspecies' package, using 1,000 permutations (De Cáceres and Legendre 2009).

Co-occurrence network analysis was conducted to examine network structure and topology, identify hub OTUs, and examine positive and negative co-occurrences within tar spot and fish-eye lesions. Nonnormalized fish-eye or tar spot OTU tables were filtered to only include OTUs with more than five reads in at least $5 \%$ of samples to minimize the influence of rare taxa on network structure. Tar spot or fish-eye networks were constructed separately with the SPIEC-EASI pipeline following the neighborhood-selection graphical model inference procedure (Kurtz et al. 2015). Network statistics of node degree (number of edges for each node) and eigenvector centrality (high degree nodes connected to other high degree nodes) were calculated from resulting tar spot or fish-eye networks using 'igraph' (Csardi and Nepusz 2006). Degree and eigenvector centrality were $\log$ transformed and nodes with values above 1.65 standard deviations from the mean $(P \leq 0.05)$ according to both statistics were considered significant network hubs (Agler et al. 2016). Networks were exported to and visualized in Cytoscape 3.7.0 (Shannon et al. 2003).

Data availability. All raw sequences were submitted to the NCBI Sequence Read Archives under BioProject PRJNA510625. All bioinformatic and analysis code are available at https://github. com/rothmi12/TarSpot_of_Corn.

\section{RESULTS}

Tar spot and fish-eye community compositions. The Illumina MiSeq run produced over 5 million reads in total, with at least 31,000 reads for all 48 samples except for one nonsymptomatic leaf sample that produced only seven reads, which was removed from analysis. A summary of taxa identified by symptomology is presented in Figure 2. The two tar spot and two fish-eye symptomatic samples that were not surface-sterilized had fungal communities that were within the $95 \%$ confidence intervals for the surfacesterilized symptom types (data not shown) and were pooled with their respective symptomologies. In total, 735 OTUs were distinguished at $>97 \%$ similarity. Of these, 608 were classified taxonomically to at least the phylum level. Phyllachora maydis was present in all symptomatic samples (approximately $45 \%$ of reads). It was even detected in low abundance in nonsymptomatic samples (approximately $4 \%$ of the reads) (Fig. 2). Other genera in symptomatic tissues were also in high abundances. Alternaria represented approximately $20 \%$ of reads in both symptoms, Paraphaeosphaeria represented approximately $3 \%$ of reads in tar spot samples and $18 \%$ of reads in fish-eye samples, and Fusarium represented approximately $2 \%$ of reads in tar spot samples and $20 \%$ of reads in fish-eye samples (Fig. 2).

Community diversity measurements. Within sample $(\alpha)$ diversity was significantly different between tar spot and fish-eye samples according to Shannon's diversity index (Fig. 3A). Tar spot lesions had significantly higher species richness (Fig. 3B) and species evenness (Fig. 3C) compared with fish-eye lesions. Differences in $\beta$-diversity of fungal communities of each symptom class were visually examined using principal coordinates analysis (PCoA) at a 95\% confidence interval on a pruned dataset containing 218 taxa that appeared at least five times in at least $5 \%$ of the samples. The different fungal communities and their dispersions are 
represented using Bray-Curtis (Fig. 4A) and Jaccard distances (Fig. 4B). The first and second axes explained 45.1 and $21.1 \%$ or 32.9 and $17.0 \%$ of the variance in Bray-Curtis or Jaccard distances, respectively (Fig. 4). PCoA on Bray-Curtis (considering abundance) and Jaccard (presence/absence) indices produced similar clusters with fish-eye communities associated with positive axis one and two scores, whereas tar spot communities were more associated with negative axis one scores. A PERMANOVA between tar spot and fish-eye samples ( $\beta$-diversity) indicated that lesion type had a significant effect on fungal communities $(P<$ 0.001 ), while each community also had significantly different community dispersions, with fish-eye communities being more dispersed than tar spot $(P<0.001)$. Similar clustering with Jaccard and Bray-Curtis distances indicated that differences in fungal communities observed in tar spot lesions and fish-eye symptoms were driven by the presence/absence of particular taxa, rather than differences in their abundance.

OTUs associated with fish-eye symptoms. OTUs that were outside the $95 \%$ confidence interval of the tar spot community were highlighted for further investigation (Fig. 4, arrows). Fourteen candidate OTUs were highlighted from PCoA plots based on their distance from the tar spot confidence interval and orientation in the fish-eye confidence interval. Their taxonomy was identified with both CONSTAX and NCBI BLAST based on their ITS1 sequence (Table 1). Three of these candidates manually highlighted in the PCoA analysis were also identified with indicator species analysis and identified with BLAST analysis as OTU_2 (Neottiosporina paspali at 91\% identity), OTU_33 (Phyllachora maydis at $95 \%$ identity), and OTU_262 (Phyllachora maydis at 98\% identity $(P<$ 0.02) (Table 2). Two other OTUs that were not from the PCoA (OTU_6 Paraphaeosphaeria neglecta and OTU_7 Fusarium sporotrichioides) were also identified as significant indicators of fish-eye lesions (Table 2). ANCOM identified seven OTUs significantly more abundant in tar spot lesions and one OTU significantly more abundant in fish-eye lesions (Table 2, Supplementary Fig. S2). One OTU (OTU_2 Fungi, putatively Neottiosporina paspali) was significantly more abundant in fish-eye symptoms identified with ANCOM and was also significantly associated with fish-eye symptoms using indicator species analysis.

Network analysis. Alpha and $\beta$-diversity measures indicated fungal communities within tar spot and fish-eye lesions were significantly different $(P<0.001)$. Therefore, network analysis was performed on the communities separately. In both tar spot and fisheye fungal coassociation networks, Phyllachora maydis OTUs group together in a strong positive association (Fig. 5). All significant hubs identified in network analysis were Phyllachora

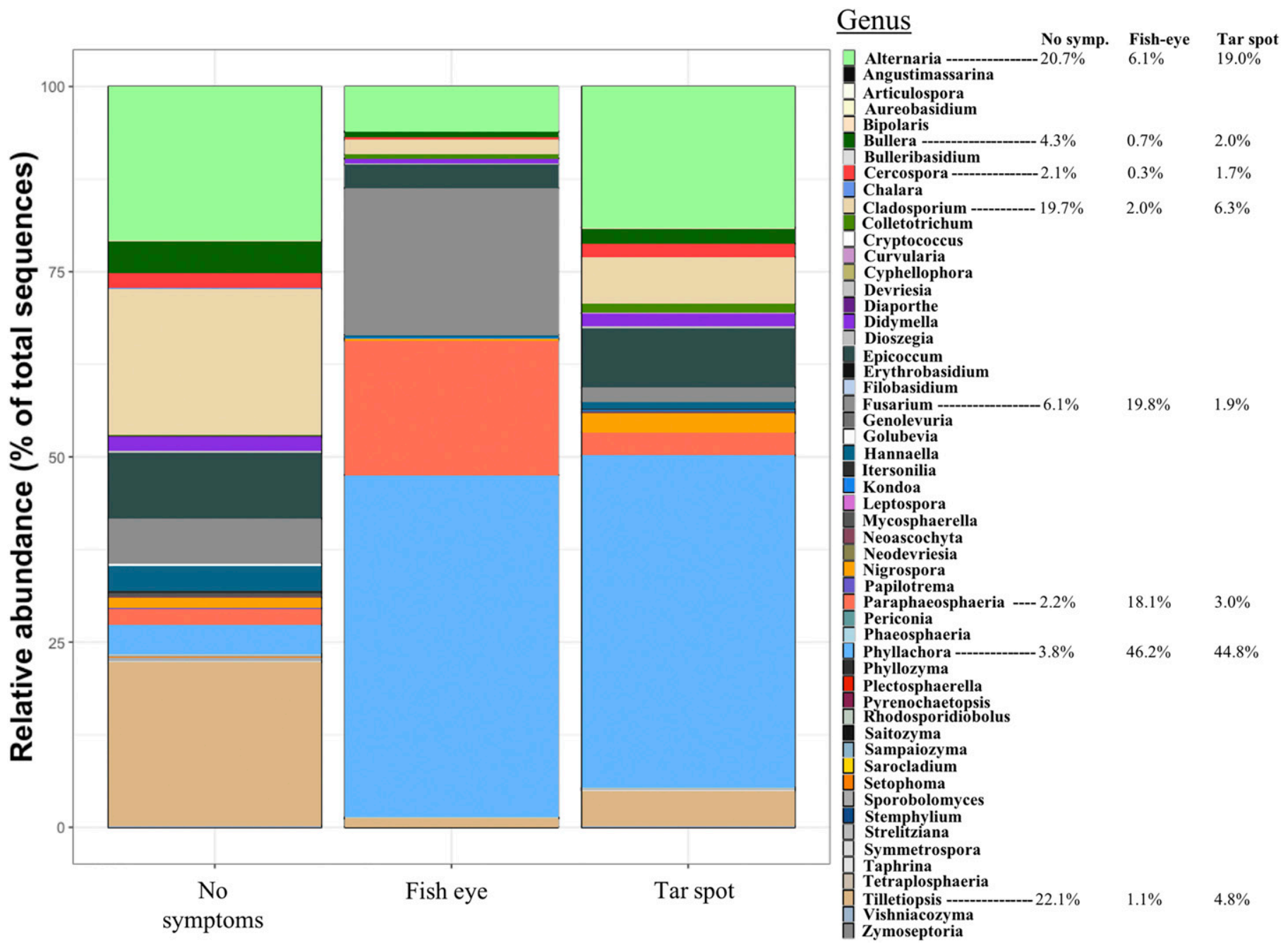

Fig. 2. The relative abundance of genera associated within samples of each lesion type. Phyllachora sp. (blue) were found in all samples. Genera of interest were designated with their percentage of total sequences within each sample type. 
A

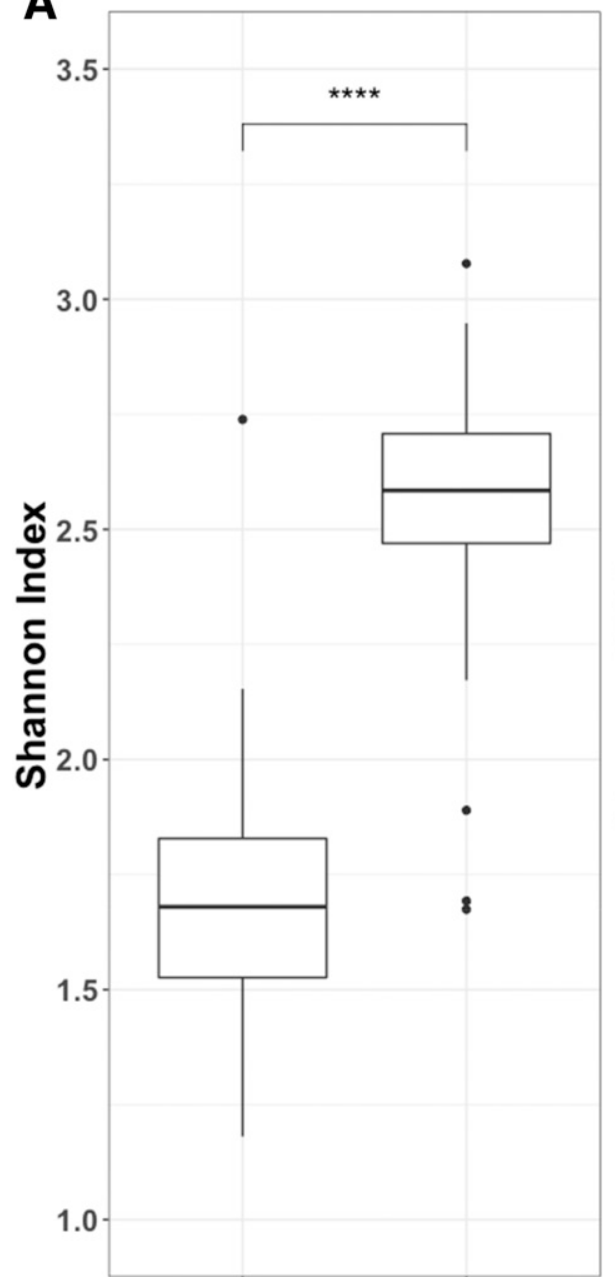

Fish eye Tar spot Lesion Type

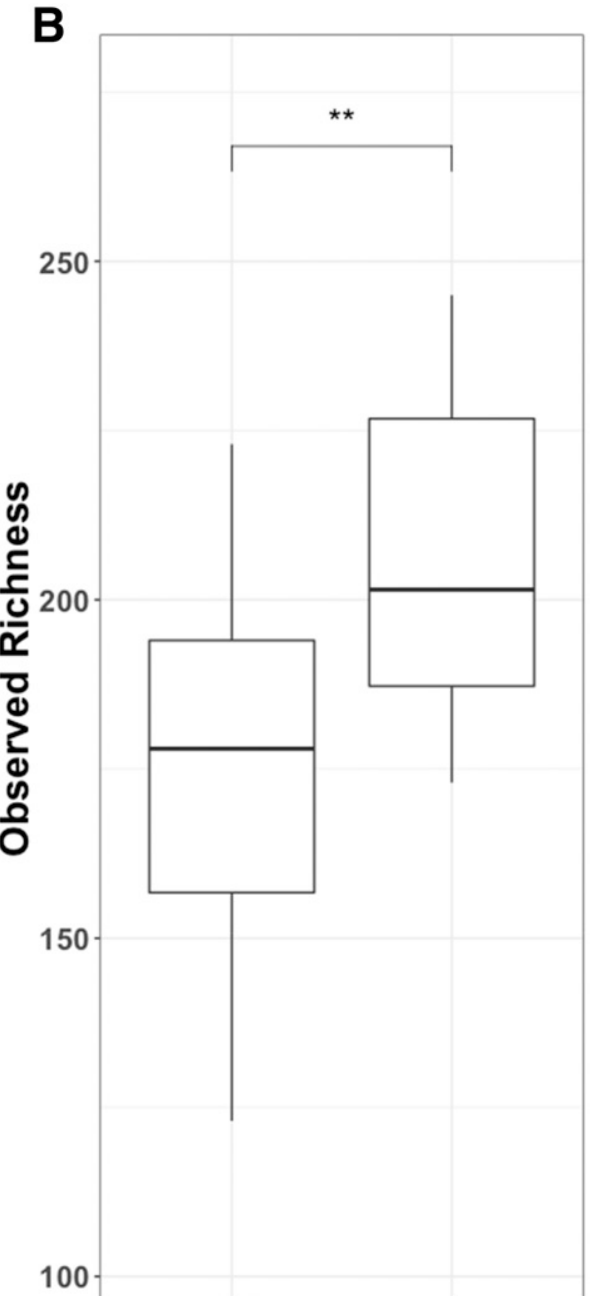

Fish eye Tar spot Lesion Type

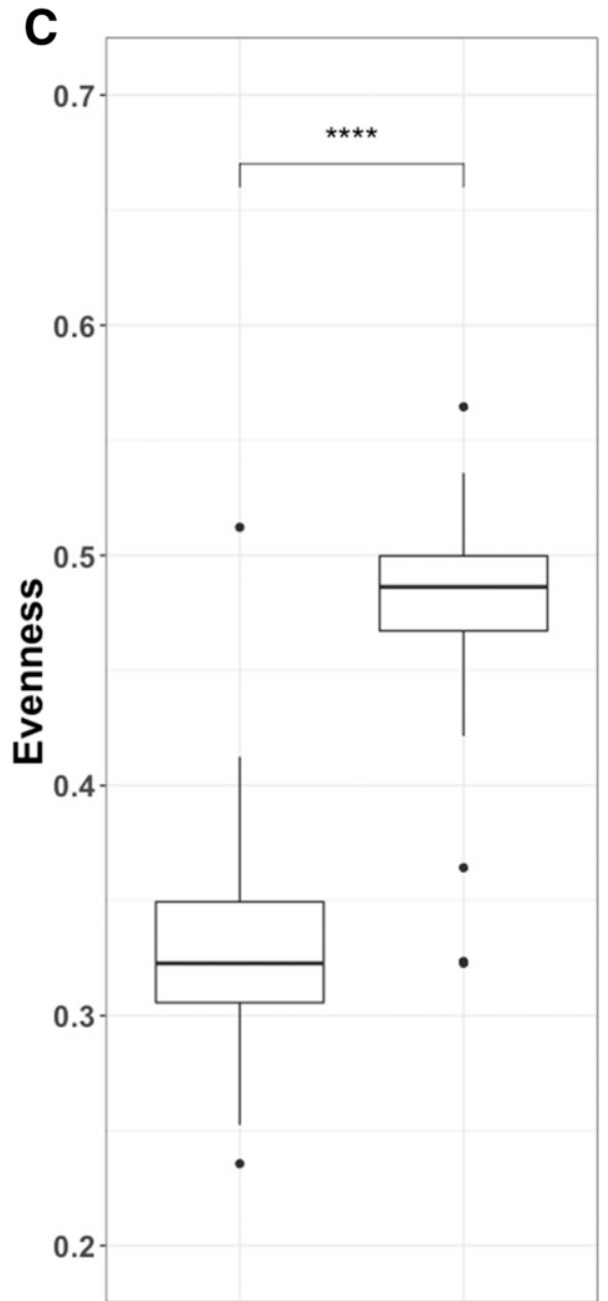

Fish eye Tar spot Lesion Type

Fig. 3. Comparison of within sample $(\alpha)$ diversity between tar spot and fish-eye lesions with A, Shannon's diversity index, B, species richness, and C, species evenness. Means were compared with the Wilcox test $(n=22)$. ${ }^{* *}$ indicates $P<0.01$, ${ }^{* * *}$ indicates $P<0.001$, and ${ }^{* * *}$ indicates $P<0.0001$.
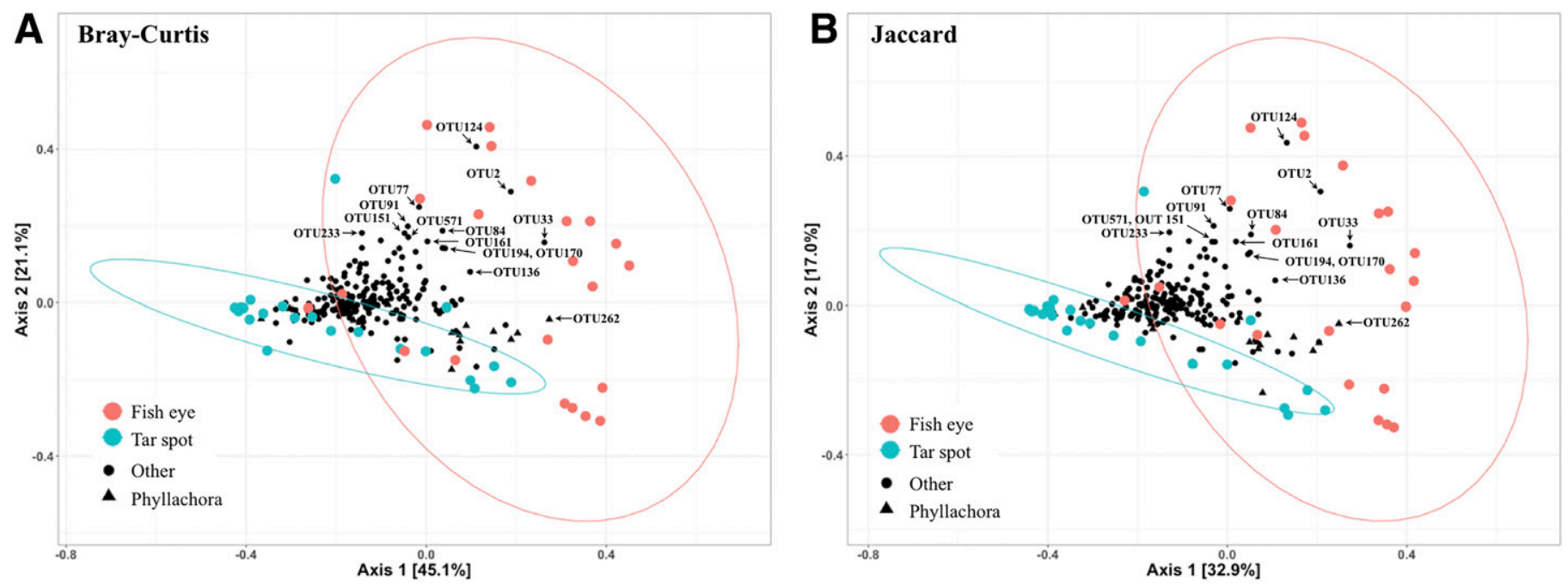

Fig. 4. Principal coordinates analysis of operational taxonomic units (OTUs) associated with lesion types calculated using A, Bray-Curtis or B, Jaccard distance measures. Ellipses represent the 95\% confidence interval for each lesion type. OTUs associated with the plot ordination are displayed as black circles. Black triangles are OTUs identified as Phyllachora maydis. OTUs that appeared to be strongly associated with fish-eye lesions were selected and labeled. 
maydis OTUs, with three identified in the tar spot network (OTU_18, OTU_186, and OTU_262) and two in the fish-eye network (OTU_1 and OTU_532), indicating the importance of Phyllachora maydis in the development of tar spot and fish-eye lesions (Fig. 5). However, fungal communities within fish-eye lesions had fewer taxa $(n=160)$ compared with the tar spot communities $(n=216)$, supporting the $\alpha$-diversity results that fisheye lesions were less diverse (Fig. 2). The candidates identified in $\beta$-diversity and indicator species analysis were highlighted in the network, revealing their connections to other taxa. OTU_2 was a terminal node in both communities; however, it was distant from Phyllachora maydis in the tar spot community and strongly positively connected to a Phyllachora maydis OTU (OTU_33) in the fish-eye community (Fig. 5). The other candidates, Fusarium sporotrichioides and Phaeosphaeria neglecta, had negative connections with Phyllachora maydis in the tar spot communities, but positive connections to Phyllachora maydis in the fish-eye communities (Fig. 5).

\section{DISCUSSION}

Next-generation sequencing offers novel opportunities for studying the association of foliar fungal communities and diseases (Lamichhane and Venturi 2015). In this study, fungal communities of foliar lesions associated with the tar spot and fish-eye lesions of corn were examined using amplicon sequencing of fungal ITS1 rDNA. Historically, tar spot of corn has been reported to be caused by Phyllachora maydis, with subsequent fish-eye symptoms developing due to Monographella maydis infections (Hock et al. 1989; Müller and Samuels 1984). As expected, Phyllachora maydis was associated with and was integral to the community structure of both tar spot and fish-eye symptoms. Interestingly, Monographella

TABLE 1

The CONSTAX and BLAST identifications of labeled operational taxonomic units (OTUs) that associated with fish-eye lesions from the principal coordinates analysis plot (Fig. 4), and associated presence/absence data in respective lesion types

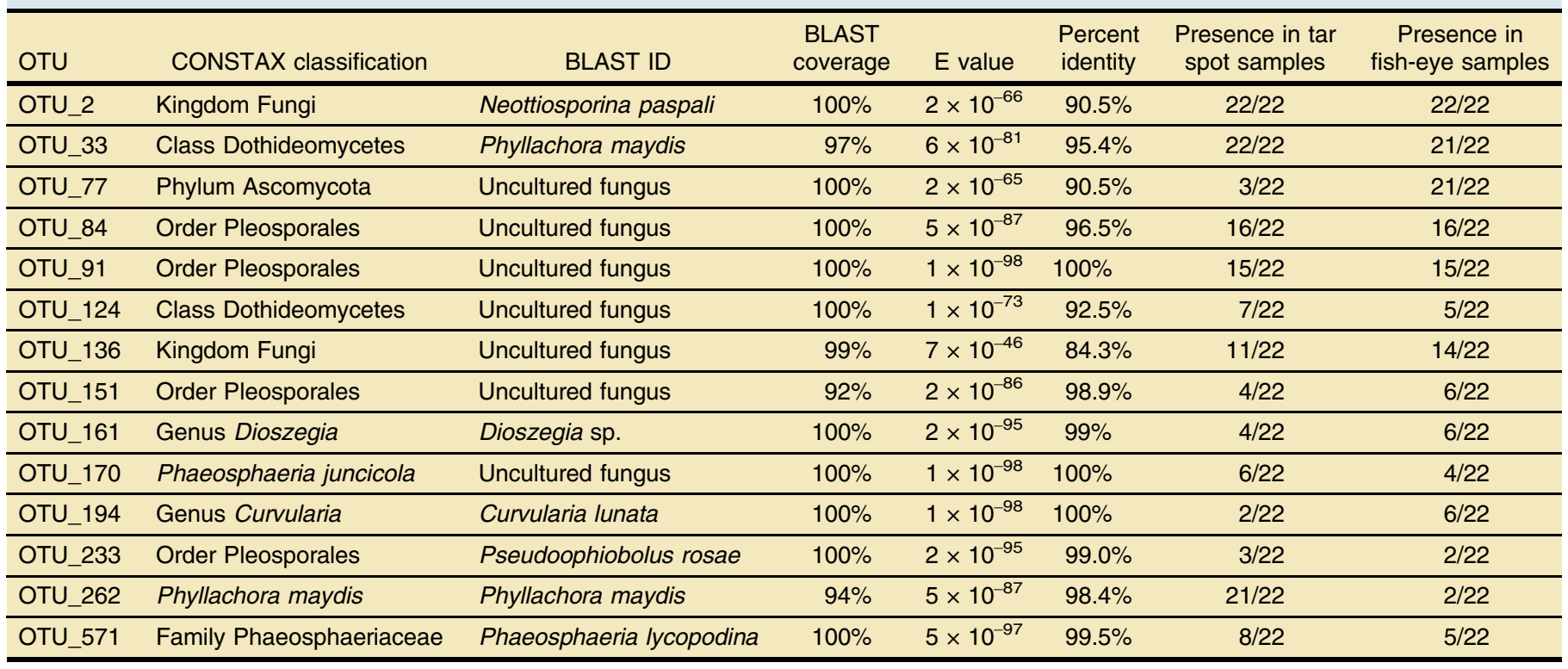

TABLE 2

Identities of significant operational taxonomic units (OTUs) associated with fish-eye lesions according to indicator species and analysis of composition of microbiomes (ANCOM) results ${ }^{\text {a }}$

\begin{tabular}{|c|c|c|c|c|c|c|c|c|c|}
\hline \multirow[b]{2}{*}{ OTU } & \multicolumn{5}{|c|}{ Taxonomy } & \multicolumn{2}{|c|}{$\begin{array}{l}\text { Indicator } \\
\text { species }\end{array}$} & \multirow{2}{*}{$\begin{array}{c}\text { ANCOM } \\
\text { Log fold } \\
\begin{array}{c}\text { change abundance } \\
\text { in fish-eye }\end{array}\end{array}$} & \multirow[b]{2}{*}{ W-statistic } \\
\hline & CONSTAX assignment & BLAST ID & $\begin{array}{l}\text { BLAST } \\
\text { coverage }\end{array}$ & $\mathrm{E}$ value & $\begin{array}{l}\text { Percent } \\
\text { identity }\end{array}$ & $\operatorname{lndVal}^{\mathrm{c}}$ & $P$ & & \\
\hline OTU_6 & $\begin{array}{l}\text { Genus } \\
\quad \text { Paraphaeosphaeria }\end{array}$ & $\begin{array}{l}\text { Paraphaeosphaeria } \\
\text { neglecta }\end{array}$ & $100 \%$ & $3 \times 10^{-93}$ & $100 \%$ & 0.945 & 0.024 & 0.606 & 13 \\
\hline OTU_33 & Class Dothideomycetes & Phyllachora maydis & $97 \%$ & $6 \times 10^{-81}$ & $95 \%$ & 0.911 & 0.002 & 1.259 & 672 \\
\hline OTU_262 & Phyllachora maydis & Phyllachora maydis & $94 \%$ & $4 \times 10^{-87}$ & $98 \%$ & 0.926 & 0.014 & 0.883 & 118 \\
\hline
\end{tabular}

a Taxa were identified with CONSTAX and BLAST.

b W-statistic represents the number of times the null hypothesis that the mean log abundance was equal between fish-eye and tar spot lesions was rejected with an FDR $<0.05$ and Benjamini and Hochberg $P$ value adjustment for multiple comparisons. * represent a significant result.

${ }^{c}$ IndVal index represents the correlation between the OTU and assignment into the fish-eye lesion category. 
sp. (syn. Microdochium sp.), were not associated with either lesion type in this study. It is important to note that no Monographella maydis ITS sequences are presently available, but our taxonomic database included Monographella sorghi (syn. Microdochium sorghi) sequences, which would allow for classification of other Monographella (syn. Microdochium) species to the genus level. Two OTUs identified as Microdochium (OTU_245 and OTU_284), but were only present in eight tar spot samples and four fish-eye

A Tar spot network

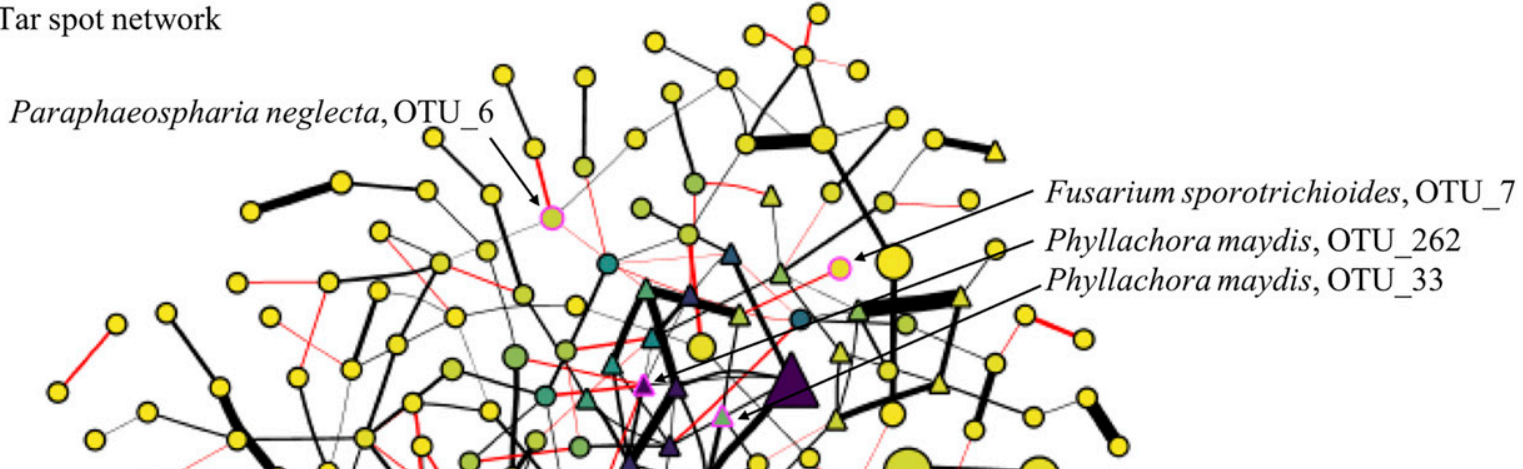<smiles>COC(O)(OC)OOCO</smiles><smiles>C1C[GeH]2CC1C2</smiles>

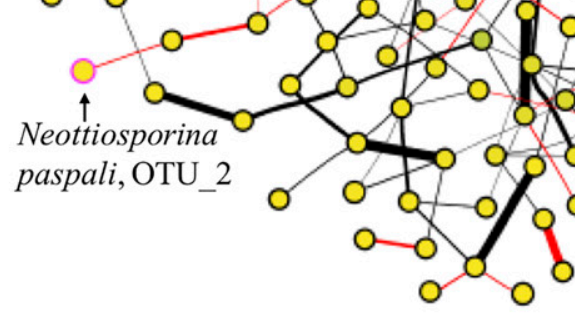

$\stackrel{\uparrow}{\uparrow}$ Neottiosporina paspali,OTU_2

\section{B Fish-eye network}

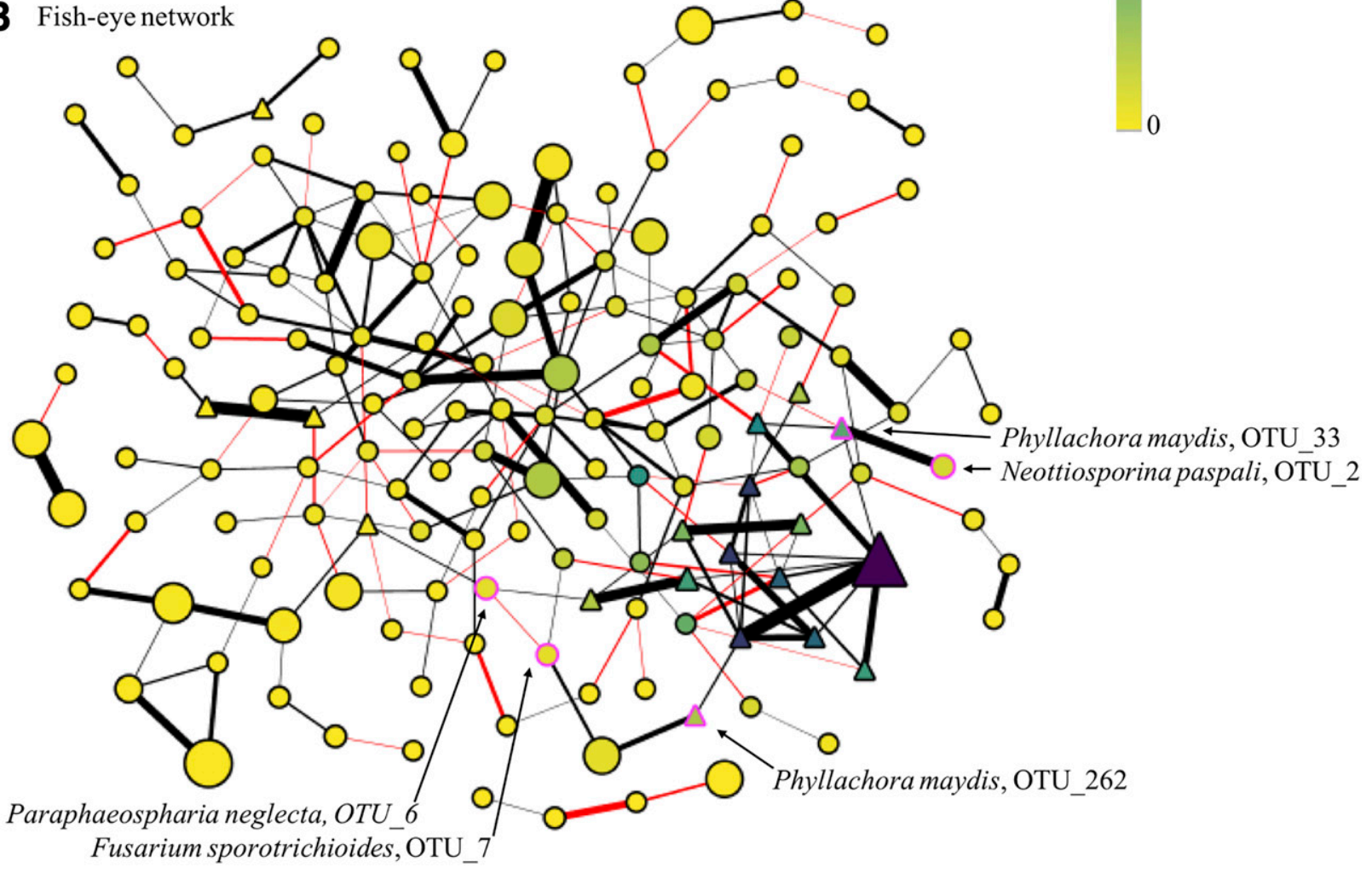

Fig. 5. Co-occurrence networks of taxa in A, tar spot and B, fish-eye symptomatic samples as estimated using the SPIEC-EASI pipeline with the neighborhood-selection graphical model inference procedure. Triangles represent Phyllachora maydis nodes, and circles represent non-Phyllachora maydis nodes. The color of connections between nodes (edges) indicate positive (black) and negative (red) interactions. Edge width indicates the strength of the interaction. Node color indicates eigenvector centrality. Nodes with high eigenvector centrality are more likely to be hub taxa. Nodes labeled with putative species assignments based on BLAST with pink border indicates operational taxonomic units (OTUs) identified to be significantly associated with fish-eye lesions using indicator species analysis or more abundant in fish-eye lesions using analysis of composition of microbiomes. 
samples, with a maximum of eight reads. These data do not support the hypothesis that Monographella maydis is required for development of fish-eye lesions in Michigan. Rather, these data identified other fungal taxa that are associated with fish-eye symptoms.

Multiple OTUs were identified as Phyllachora maydis. This result can indicate PCR bias or significant sequencing errors. However, the average phred-score of reads before and after trimming were both greater than 30 , indicating a 1 in 1,000 sequencing error rate. In addition, the stringent filtering process used allowed for only one expected error per read out of 244 total bp (>99\% sequence identity) (Edgar and Flyvbjerg 2015). Therefore, the OTUs identifying as Phyllachora maydis are likely truly diverse sequences ( $<97 \%$ conservation) (Supplementary Fig. S3). Many OTUs in this study remain unidentified, which is a common limitation of environmental sequencing studies (Schlaeppi and Bulgarelli 2015). It is possible that Monographella maydis was present in our study, but our data fails to support its requirement for the development of fish-eye lesions. Cultures of Monographella maydis from Mexico have recently been sent to the United States for molecular diagnostics and sequencing of taxonomic markers. However, the genetic characterization of these isolates places them within the Fusarium equiseti-incarnatum species complex, based on multiple gene loci (N. Kleczewski and D. Plewa, personal communication). Therefore, the absence of Monographella maydis in this study is likely an accurate result and not due to technological issues or a lack of identification.

Phyllachora maydis was present in all samples, including nonsymptomatic samples (Fig. 2). Other OTUs within the genera Alternaria, Fusarium, and Paraphaeosphaeria were in high abundance in symptomatic tissues and these genera contain known pathogens of grasses. Corn is a host for Alternaria alternata, which is known to be an opportunistic pathogen that infects the host following damage by other fungi (Weir et al. 1998). Many species in the genus Paraphaeosphaeria were recently reclassified from the genus Coniothyrium (Verkley et al. 2014), which contains a mycoparasite of Phyllachora maydis, Coniothyrium phyllachorae (Hock et al. 1995; Maublanc 1904). Fusarium sporotrichioides is also capable of causing foliar spots on corn (Moya-Elizondo et al. 2013), and was a significant indicator species in our analysis (Table 2). In addition, isolation attempts from fish-eye symptomatic field samples in Michigan have mostly yielded Fusarium species, such as Fusarium acuminatum (A. G. McCoy, data not shown). Therefore, Fusarium spp. may be candidate causal agents required for fish-eye symptom development, in contrast to the reported Monographella maydis.

Exploring the data further indicated that tar spot and fish-eye lesions differed significantly in $\alpha$ - and $\beta$-diversity (Figs. 3 and 4 ). The significant reduction in $\alpha$-diversity (Fig. 3 ) and the significant increase in $\beta$-dispersion of fish-eye samples indicate that a few species in high abundance likely dominate fish-eye lesions. Therefore, we utilized $\beta$-diversity ordination plots, indicator species analyses, ANCOM, and network analyses to identify candidate taxa responsible for the development of fish-eye symptoms. Some candidates include known or opportunistic plant pathogens in the genera Curvularia, Neottiosporina, and Phaeosphaeria. Curvularia lunata was recently reported causing leaf spot on corn in the United States (Garcia-Aroca et al. 2018). Interestingly, Curvularia lunata and Phyllachora species are known to associate together to form leaf spot on Hymenachne amplexicaulis, a perennial grass (Monteiro et al. 2003). Multiple species from the genus Neottiosporina (syn. Stagonospora) have been reported to cause leaf spots on wheat and sorghum (Nagelkirk 2010; Sutton and Wu 1995; University of Illinois
Extension 1991). Neottiosporina paspali was previously classified in the genus Stagonospora until a reclassification in 1974 (Sutton and Alcorn 1974), and many Stagonospora species cause necrotic leaf spot diseases on grasses. However, molecular sequences for most Neottiosporina species are lacking, and OTU_2 likely represents one of these species within the genus $\mathrm{Neo}$ ttiosporina, hence the $91 \%$ BLAST identity to Neottiosporina paspali. Phaeosphaeria maydis was formerly thought to cause the disease Phaeosphaeria leaf spot, but the bacterium Pantoea ananatis was later found to be the causal agent of the leaf spot. Pantoea ananatis causes the symptoms associated with Phaeosphaeria leaf spot and when the bacterium co-occurs with the fungus Phaeosphaeria maydis are elevated $>10 \%$ yield loss is observed in some corn hybrids (Carson 2005; Gonçalves et al. 2013). Other candidates that could potentially cause secondary infection include Pseudoophiobolus rosae, a known saprophyte, and Dioszegia spp., which are known phylloplane yeasts tolerant to extreme conditions, and found to be significant hub taxa in the Arabidopsis thaliana phyllosphere (Agler et al. 2016). Bacterial communities were beyond the scope of this study; however, it must be acknowledged that bacteria could be involved in this disease, but there is no evidence or reason to believe that bacteria are responsible for these symptoms.

The frequent identification of OTU_2, associated with fish-eye symptoms in PCoA, indicator species analysis, and ANCOM is intriguing. Visualizing its connection to Phyllachora maydis in network analysis indicates that it is strongly associated with Phyllachora maydis only when fish-eye lesions develop. In contrast, the positions of Fusarium sporotrichioides and Phaeosphaeria neglecta indicate that they may be common to the corn phylloplane mycobiome, increasing in abundance as saprophytes after the development of necrotic tissue. Network analysis also revealed different connections between the multiple Phyllachora maydis OTUs (Fig. 5). Only one particular Phyllachora maydis OTU had a strong positive connection to OTU_2, a Neottiosporina paspali relative, which could indicate that fish-eye symptom development is dependent on different Phyllachora-Neottiosporina genotype interactions. In addition, corn genotype and environmental conditions may play a significant role in symptom expression. Another interesting observation in both networks was a strong negative connection between Phyllachora maydis and phylloplane yeasts in the genera Dioszegia and Bullera. An investigation into the direct interactions between Phyllachora maydis and phylloplane yeasts could reveal potential target taxa for phylloplane yeasts as a biological control against Phyllachora maydis.

In conclusion, this study provides strong evidence that the development of fish-eye lesions in the tar spot disease complex of corn in Michigan does not require Monographella maydis. Instead, we suggest two alternative hypotheses with supporting evidence. First, Phyllachora maydis may allow for secondary infections by multiple fungal species that are capable of causing necrotic fish-eye symptoms independently. Of candidate taxa identified in this study, OTU_2 (a relative of Neottiosporina paspali) is of particular interest and attempts at isolation and fulfillment of Koch's postulates should be performed (Koch 1876). Second, individual genotypes or populations of Phyllachora maydis could be responsible for all symptoms in the tar spot disease complex, as certain Phyllachora maydis OTUs (i.e., genotypes) were significant indicators of fish-eye symptoms and hub taxa in fish-eye networks. The development of a reproducible inoculation procedure for Phyllachora maydis and reproduction of both tar spot and fish-eye symptoms will aid in testing of both hypotheses. 


\section{ACKNOWLEDGMENTS}

We thank Gian Maria Niccolò Benucci for his guidance and suggestions on data analysis.

\section{LITERATURE CITED}

Agler, M. T., Ruhe, J., Kroll, S., Morhenn, C., Kim, S.-T., Weigel, D., and Kemen, E. M. 2016. Microbial hub taxa link host and abiotic factors to plant microbiome variation. PLoS Biol. 14:e1002352.

Caporaso, J. G., Kuczynski, J., Stombaugh, J., Bittinger, K., Bushman, F. D., Costello, E. K., Fierer, N., Gonzalez Peña, A., Goodrich, J. K., Gordon, J. I., Huttley, G. A., Kelley, S. T., Knights, D., Koenig, J. E., Ley, R. E., Lozupone, C. A., McDonald, D., Muegge, B. D., Pirrung, M., Reeder, J., Sevinsky, J. R., Turnbaugh, P. J., Walters, W. A., Widmann, J., Yatsunenko, T., Zaneveld, J., and Knight, R. 2010. QIIME allows analysis of high-throughput community sequencing data. Nat. Methods 7:335-336.

Carson, M. L. 2005. Yield loss potential of Phaeosphaeria leaf spot of maize caused by Phaeosphaeria maydis in the United States. Plant Dis. 89:986-988.

Chalkley, D. S. 2010. Tar spot of corn-Phyllachora maydis. Systematic Mycology and Microbiology Laboratory, ARS, USDA. Invasive Fungi. https://nt.ars-grin.gov/taxadescriptions/factsheets/index.cfm? thisapp $=$ Phyllachoramaydis

Chen, K. H., Liao, H. L., Arnold, A. E., Bonito, G. M., and Lutzoni, F. 2018. RNA-based analyses reveal fungal communities structured by a senescence gradient in the moss Dicranum scoparium and the presence of putative multitrophic fungi. New Phytol. 218:1597-1611.

Csardi, G., and Nepusz, T. 2006. The igraph software package for complex network research. InterJournal Complex Systems 1695. https://igraph.org

De Cáceres, M., and Legendre, P. 2009. Associations between species and groups of sites: Indices and statistical inference. Ecology 90:3566-3574.

Edgar, R. C. 2013. UPARSE: Highly accurate OTU sequences from microbial amplicon reads. Nat. Methods 10:996-998.

Edgar, R. C., and Flyvbjerg, H. 2015. Error filtering, pair assembly and error correction for next-generation sequencing reads. Bioinformatics 31:3476-3482.

Garcia-Aroca, T., Doyle, V., Singh, R., Price, T. and Collins, K. 2018. First report of Curvularia leaf spot of corn, caused by Curvularia lunata, in the United States. Plant Health Progress 19:140-142.

Gardes, M., and Bruns, T. D. 1993. ITS primers with enhanced specificity for Basidiomycetes, application to the identification of mycorrhizae and rusts. Mol. Ecol. 2:113-118.

Gdanetz, K., Benucci, G. M. N., Vande Pol, N., and Bonito, G. 2017. CONSTAX: A tool for improved taxonomic resolution of environmental fungal ITS sequences. BMC Bioinformatics 18:538.

Gonçalves, R. M., Figueiredo, J. E. F., Pedro, E. S., Meirelles, W. F., Leite, R. P., Jr., Sauer, A. V., and Paccola-Meirelles, L. D. 2013. Etiology of Phaeosphaeria leaf spot disease of maize. J. Plant Pathol. 95:559-569.

Hock, J., Dittrich, U., Renfro, B. L., and Kranz, J. 1992. Sequential development of pathogens in the maize tarspot disease complex. Mycopathologia 117:157-161.

Hock, J., Kranz, J., and Renfro, B. 1989. El complejo 'mancha de asfalto' de maíz: Su distribucción geográfica, requisitos ambientales e importancia económica en México. Rev. Mex. Fitopatol. 7:129-135.

Hock, J., Kranz, J., and Renfro, B. L. 1995. Studies on the epidemiology of the tar spot disease complex of maize in Mexico. Plant Pathol. 44:490-502.

Koch, R. 1876. Untersuchungen über Bakterien: V. Die Ätiologie der Milzbrand-Krankheit, begründet auf die Entwicklungsgeschichte des Bacillus anthracis. [Investigations into bacteria: V. The etiology of anthrax, based on the ontogenesis of Bacillus anthracis]. Cohns Beitr. Biol. Pflanzen 2:277-310 (in German).

Kurtz, Z. D., Müller, C. L., Miraldi, E. R., Littman, D. R., Blaser, M. J., and Bonneau, R. A. 2015. Sparse and compositionally robust inference of microbial ecological networks. PLOS Comput. Biol. 11:e1004226.

Lamichhane, J. R., and Venturi, V. 2015. Synergisms between microbial pathogens in plant disease complexes: A growing trend. Front. Plant Sci. 6:385.

Lundberg, D. S., Yourstone, S., Mieczkowski, P., Jones, C. D., and Dangl, J. L. 2013. Practical innovations for high-throughput amplicon sequencing. Nat. Methods 10:999-1002.

Mandal, S., Van Treuren, W., White, R. A., Eggesbø, M., Knight, R., and Peddada, S. D. 2015. Analysis of composition of microbiomes: A novel method for studying microbial composition. Microbiol. Ecol. Health Dis. 26:27663.
Martin, M. 2011. Cutadapt removes adapter sequences from high-throughput sequencing reads. EMBnet.journal 17:10-12.

Maublanc, A. 1904. Espèces nouvelles de champignons inferieurs. Bull. Soc. Mycol. Fr. 20:70-74.

McCoy, A. G., Romberg, M. K., Zaworski, E. R., Robertson, A. E., Phibbs, A., Hudelson, B. D., Smith, D. L., Beiriger, R. L., Raid, R. N., Byrne, J. M., and Chilvers, M. I. 2018. First report of tar spot on corn (Zea mays) caused by Phyllachora maydis in Florida, Iowa, Michigan, and Wisconsin. Plant Dis. 102:1851.

McMurdie, P. J., and Holmes, S. 2013. phyloseq: An R package for reproducible interactive analysis and graphics of microbiome census data. PLoS One 8: e61217.

McMurdie, P. J., and Holmes, S. 2014. Waste not, want not: Why rarefying microbiome data is inadmissible. PLOS Comput. Biol. 10:e1003531.

Michie, M. G. 1982. Use of the Bray-Curtis similarity measure in cluster analysis of foraminiferal data. J. Int. Assoc. Math. Geol. 14:661-667.

Monteiro, F. T., Vieira, B. S., and Barreto, R. W. 2003. Curvularia lunata and Phyllochora sp.: Two fungal pathogens of the grassy weed Hymenachne amplexicaulis from Brazil. Australas. Plant Pathol. 32:449-453.

Moya-Elizondo, E. A., Arismendi, N., Montalva, C., and Doussoulin, H. 2013. First report of Fusarium sporotrichioides causing foliar spots on forage corn in Chile. Plant Dis. 97:1113.

Mueller, D. S., Wise, K. A., Sisson, A. J., Allen, T. W., Bergstrom, G. C., Bosley, D. B., et al. 2017. Corn disease loss estimates from the United States and Ontario, Canada-2016. Iowa State University. https://store.extension.iastate.edu/ product $/ 15375$

Müller, E., and Samuels, J. G. 1984. Monographella maydis sp. nov. and its connection to the tarspot disease of Zea mays. Nova Hedwigia 40:113-121.

Nagelkirk, M. 2010. Stagonospora leafspot on wheat. Michigan State University Extension. https://www.canr.msu.edu/news/stagonospora_leafspot_on_wheat

Oksanen, J., Blanchet, F. G., Friendly, M., Kindt, R., Legendre, P., and McGlinn, D. 2016. vegan: Community ecology package. https://CRAN.Rproject.org/web/packages/vegan/index.html

Pereyda-Hernández, J., Hernández-Morales, J., Sandoval-Islas, J. S., ArandaOcampo, S., de León, C., and Gómez-Montiel, N. 2009. Etiologia y manejo de la mancha de asfalto (Phyllachora maydis Maubl.) del maiz en Guerrero, Mexico. Agrociencia 43:511-519.

R Core Team. 2017. R: A Language and Environment for Statistical Computing. R Foundation for Statistical Computing, Vienna, Austria.

Real, R., and Vargas, J. M. 1996. The probabilistic basis of Jaccard's index of similarity. Syst. Biol. 45:380-385.

Ruhl, G., Romberg, M. K., Bissonnette, S., Plewa, D., Creswell, T., and Wise, K. A. 2016. First report of tar spot on corn caused by Phyllachora maydis in the United States. Plant Dis. 100:1496.

Schlaeppi, K., and Bulgarelli, D. 2015. The plant microbiome at work. Mol. Plant-Microbe Interact. 28:212-217.

Shannon, P., Markiel, A., Ozier, O., Baliga, N. S., Wang, J. T., Ramage, D., Amin, N., Schwikowski, B., and Ideker, T. 2003. Cytoscape: A software environment for integrated models of biomolecular interaction networks. Genome Res. 13:2498-2504.

Sutton, B. C., and Alcorn, J. L. 1974. Neottiosporina. Aust. J. Bot. 22: 517-530.

Sutton, B. C., and Wu, W. P. 1995. Neottiosporina sorghicola sp. nov., associated with leaf lesions on Sorghum vulgare from China. Mycol. Res. 99: 831-832.

University of Illinois Extension. 1991. Stagonospora leaf spot or blotch of forage grasses. Report on Plant Diseases. https://ipm.illinois.edu/diseases/rpds/ 312.pdf.

Verkley, G. J. M., Dukik, K., Renfurm, R., Göker, M., and Stielow, J. B. 2014. Novel genera and species of coniothyrium-like fungi in Montagnulaceae (Ascomycota). Persoonia 32:25-51.

Weir, T. L., Huff, D. R., Christ, B. J., and Romaine, C. P. 1998. RAPD-PCR analysis of genetic variation among isolates of Alternaria solani and Alternaria alternata from potato and tomato. Mycologia 90:813-821.

White, T. J., Bruns, T. D., Lee, S. B., and Taylor, J. W. 1990. Amplification and direct sequencing of fungal ribosomal RNA genes for phylogenetics. Pages 315-322 in: PCR Protocols-A Guide to Methods and Applications. M. A. Innis, D. H. Gelfand, J. J. Sninsky, and T. J. White, eds. Academic Press, San Diego, CA.

Wickham, H. 2009. ggplot2: Elegant Graphics for Data Analysis. Springer, New York. 